\begin{tabular}{|c|c|c|}
\hline $\begin{array}{l}\text { FATIIH } \\
\text { SULTAN } \\
\text { MEHMET } \\
\text { VAKIF ÜNIVERSITESI } \\
2010\end{array}$ & $\begin{array}{l}\text { FSM İlmî Araştırmalar Insan ve Toplum Bilimleri Dergisi } \\
\text { FSM Scholarly Studies Journal of Humanities and Social Sciences } \\
\text { Sayı/Number } 14 \text { Yıl/Year } 2019 \text { Güz/Autumn } \\
\text { (C2019 Fatih Sultan Mehmet Vakıf Üniversitesi }\end{array}$ & arising \\
\hline DOI: & http://dergipark.org.tr/fsmia & http://dergi.fsm.edu.tr \\
\hline Araştırma Makalesi / Research Article & - Geliş Tarihi / Received: 11.10.2019 Kabul Tarihi / Accepted: 15.11.2019 & FSMIAD, 2019; (14): 383-398 \\
\hline
\end{tabular}

\title{
Mevzû Hadislerin Tespit ve Tenkidinde Metin Bilgi ve Birikiminin Önemi
}

Halil İbrahim Kutlay*

\section{$\ddot{O} z$}

İlim ve sanatla uzun süre meşguliyet, sahibine özel bir "meleke” kazandırmakta, alan çalışmalarında süratle karar verebilme imkânı sağlamaktadır. Hadis metinleriyle uzun süre meşgul olma sonucu elde edilen metin bilgi ve birikimi sayesinde hadislerin orijinalliğini tespit etme bir "meleke" haline gelmekte, hadislerin güvenilirlik derecesi kolaylıkla belirlenmektedir. Hadis âlimleri tarafından hadisin güvenilirliğini test etme konusunda hadis râvilerinin tek tek detaylı bir şekilde incelenmesi anlamındaki sened tenkidi ile birlikte metin tenkidi için de objektif kriterler konulmuştur. Hadis metinlerinin tenkidinde Kur'an ve Sahih Sünnet gibi temel referanslara uygunluk yanında; hadisin selim akıl, tarihî gerçekler ve ilmî verilere aykırı olmaması temel esaslar olarak kabul edilmiştir. Hadis literatüründe özellikle mevzû hadislerin tenkidinde dikkate alınan bu meşhur temel esaslar dışında bazı önemli kriterlerin da zikredildiği görülmektedir. Münekkit hadis âlimlerinin hadis metinleri üzerinde tarih boyunca süren titiz ilmî çalışmaları sonunda tümevarım yoluyla vardıkları sonuçlar, ilim erbabı arasında "genel kabul" görmüştür. Bu makalede hadislerin tenkidinde metin bilgi ve birikiminin önemini gösteren ve ilim dünyasında genel kabul gören bu ilmî kriterler üzerinde durulmaktadır.

Anahtar Kelimeler: Hadis, mevzû hadis, sened tenkidi, metin tenkidi.

* Doç. Dr., Fatih Sultan Mehmet Vakıf Üniversitesi İslâmî İlimler Fakültesi, İstanbul/Türkiye, halilkutlay@fsm.edu.tr, orcid.org/0000-0002-3318-2977 


\title{
The Importance of Text Knowledge and Accumulation in the Determination and Evaluation of Fabricated Hadiths
}

\begin{abstract}
Long-term engagement with a science and art gives its performer a special talent, allowing him to make rather quick decisions without an existent evidence. As a result of being occupied with the hadith texts for a long time and with the help of the knowledge acquired during this period, it becomes a talent to easily determine the reliability of the hadiths without the need for deep research. In order to test the reliability of the hadith, in addition to analyzing the hadith in detail; an objective criterion have been set for the criticism of the hadith by the hadith scholars. Conformity with the Quran, compliance with the basic principles of religion, conformity with the Sahih Sunnah and compliance with scientific data and historical facts are the main criteria that is accepted in the criticism of the hadith texts. A number of additional rules have been established along with these basic criteria and Hadith scholars presented these significant results to the scientific world as important additional criteria in text criticism which received general acceptance among the scientists. In this article, these additional criteria which highlight the importance of text knowledge and accumulation in the criticism of hadiths are featured.
\end{abstract}

Keywords: Hadith, fabricated hadith, criticism of the shcolars, criticism of the text. 


\section{Giriş}

İlim ve sanatla uzun süre meşguliyet, sahibine özel bir "meleke" kazandırmakta, herhangi bir delil veya karine gerekmeksizin kolaylıkla karar verme imkânı vermektedir. Güzel sesin ahengini tespitte kulak hassasiyeti, güzel kokunun kalitesini tespitte burun hassasiyeti önemlidir.

Hz. Peygamber gibi en son Rasûlün, en üstün insanın, en nezih şahsiyetin mübarek ağzından dökülen ifadelerde bulunan tatlılık, ahenk ve güzelliğin tespiti de hadis ilimlerini öğrenme ve öğretme yolundaki süreklilik ve duyarlılıkla mümkündür.

Hadis metinleriyle uzun süre meşguliyet, hadisin bir "meleke" haline gelmesine sebep olmakta, hadis âlimleri hadis metinleriyle sürekli meşgul olma sonunda elde ettikleri metin bilgi ve birikimi sayesinde derin araştırmaya ihtiyaç duymadan sahih hadisleri kolaylikla tanıma kabiliyeti elde etmektedirler.

Hadis âlimleri, hadislerle ömür boyu ciddiyetle meşgul olmaları sebebiyle hadisteki nuru fark edebilmekte, o nur sayesinde kesin delillere ulaşmadan bile o rivayetin gerçekten hadis olup olmadığını anlayabilmektedirler.

Sahih hadisteki nuru veya mevzû hadisteki zulmeti fark edebilmek için basiret yanında yılların birikimi ve deneyimi söz konusudur. Nitekim bu konuda değerli sahabî Abdullah b. Mes'ud'un talebesi Rabî' b. Huseym (ö. 65/685): “Hadisin gündüz ışığı gibi ışı̆̆ı vardır ki, sen bu ışıkla onu bilirsin. Ya da onda öyle bir karanlık vardır ki, sen bu karanlık sebebiyle onun hadis olmadı̆̆ kanaatine varırsin," demektedir. Meşhur muhaddis Abdurrahman b. Mehdî ise, (ö.198/813) Basralı birini naklettiği hadis sebebiyle tenkit etmiş; arkadaşımız hakkında bunu nereden söyledin? diyenlere: "Sen de benim gibi yirmi yıl bu işi yap, benim bildiğimi bilirsin, " diye cevap vermiştir. ${ }^{2}$

Hatib el-Bağdadî (ö.463/1071) hadis ilmine en çok benzeyen mesleğin sarraflık olduğunu; ehil olan sarrafin altın ve gümüşün ayarını ve değerini, sahte olup olmadığını görür görmez bildiğini ifade etmiş; "Hadisleri temyiz etmek de böyledir. Bu ilim, uzun süre meşguliyet ve özen gösterme sonunda Allah'in kalplerde yarattı̆̆ bir ilimdir, " demiştir. ${ }^{3}$

İbnü'l-Kayyim de, (ö.751/1350) konuyla ilgili: "Senedine bakılmadan mevzû hadisi belirli bir kriterle bilmek mümkün müdür? şeklindeki soruya; $B u$, çok önemli bir sorudur. Bunu ancak sahih sünnet ilminde derinleşen, etiyle kanıyla

1 Ahmed b. Hanbel, Zühd, s.407; Hatib, el-Kifâye, s.471; Süyûtî, Tedribü'r-râvî, III, 431.

2 Hatib, el-Câmi, II, 256.

3 Hatib, el-Câmi, II, 255. 
sünnetle içiçe olan, bu konuda meleke kazanmış olan, sünnet ve eserleri tanımada derin ihtisas sahibi olan kimse bilebilir." diye cevap verirken; Siraceddin elBulkînî de (ö. 805/1403), bu görüşü destekleme sadedinde: "Bunun şahidi şudur ki, bir kimse bir üstada ylllarca hizmet etse, dolaylstyla onun sevdiği ve sevmediği şeyleri öğrense, başka bir kimse de o üstadın sevmediği bir şeyi sevdiğini iddia etse, bunu duyar duymaz hemen yalanlamaya yönelir," "4 demiştir.

Sened tenkidinin isabetli ve başarılı olması için; hadis ricalinin cerh ve ta' dîli konusunda büyük bir titizlikle çalışan, binlerce râvinin biyografilerini ve rivayetlerini detaylı bir şekilde inceleyip değerlendiren münekkit hadis âlimleri tarafindan, metin tenkidi için de objektif kriterler konulmuştur.

\section{Mevzû Hadislerin Tespit ve Tenkid Kriterleri}

\section{A. Metin Tenkidinin Temel Kriterleri}

Hadis metinlerinin tenkidinde Kur'an, sahih sünnet, selim akı1, tarihî gerçekler, dinin temel esasları ve ilmî verilere uygunluk temel kriterler olarak kabul edilmiştir.

Hatib el-Bağdadî (ö.463/1071: “Aklın hükmüne, Kur'an'ın sabit muhkem hükmüne, bilinen sünnete, sünnet olarak uygulanan davranışlara ve kesin delillere aykırı olan haber-i vahid kabul edilmez. "5 derken, İbnü'l-Cevzî de (ö.597/1218), "Şu ifade ne kadar güzeldir: Hadisin; akla ters, nakle aykırl ve usul ile çelişkili olduğunu görürsen bil ki, o hadis, mevzûdur. "' şeklinde kanaat belirtmiştir.

İbnü'l-Kayyim, el-Menaru'l-Münîf adlı eserinde hadisin mevzû olduğunu bildiren küllî bazı kriterlerin olduğuna dikkat çekmiş ${ }^{7}$ ve bu kriterlerı mevzû hadislerden seçtiği örneklerle açıklamıştır. ${ }^{8}$

İbn Kesir (ö.774/1373) $)^{9}$ İbn Hacer (ö.852/1449) $)^{10}$, Süyûtî (ö.911/1505) ${ }^{11}$, Ali el-Karî (ö.1014/1605) $)^{12}$ ve diğer pek çok âlim, hadis usûlü (ile ilgili eserlerinde Mevzû Hadis'in alâmetlerini beyan ederken benzer ifadeler kullanmışlardır. Hadisin mevzû olduğuna delâlet eden bu ilkelerin hadis âlimleri arasında ge-

4 Bülkînî, Mehâsinü'l-lstılah, s.283; Süyûtî, Tedribü'r-râvî, III, 432.

5 Hatib, el-Kifâye, s. 472.

6 İbnü'l-Cevzî, el-Mevzûât, I, 103.

7 İbn Kayyim, el-Menâru'l-münîf, s.50.

8 İbn Kayyim, a.g.e, s.50-63.

9 bkz. Şakir, el-Bâisü'l-Hasis, s.78.

10 İbn Hacer, Nüzhetü'n-nazar, s.90.

11 Süyûtî, Tedribü'r-râvî, III, 434.

12 Ali el-Karî, Şerhu şerhi'n-Nuhbe, s.443. 
nel kabul gören ilkeler olduğu anlaşılmaktadır. Ancak metin tenkidi kriterleri, matematiksel kesinlik ifade eden kriterler olmayıp yoruma ve tartışmaya açık kriterlerdir. Dolayısıyla bu konuda geniş inceleme yapılması ve ihtiyatlı ifadeler kullanılması tavsiye edilmektedir.

Nitekim bu konuda Salahaddin Polat şu tespiti yapmaktadır: "Kur'an'a ayklrllı gibi kanıt ve karineler; matematiksel sağlama yapma yöntemleri gibi herkesin kolaylıkla anlayabileceği mekanik, rutin kriterler değil, yorumsal kriterlerdir. Bu yüzden İslamiyetin ilk asırlarından beri hem teorik, hem pratik anlamda tartışılmışlardır ve tartışılmaktadırlar. Örneğin İbn Kuteybe, mütekellimûn dediği kişilerin "Kur'an'a ve akla aykırı" diye eleştirdikleri çok sayıda hadiste böyle bir aykırılık olmadı̆̆ını göstermek için Te'vilü Muhtelefi'l-Hadis isimli eserini yazmıştır." "13

Yaşadığı dönemde akılcı mutezile akımına karşı ciddî bir mücadele sergileyen İbn Kuteybe (ö.276/889), Te'vilü Muhtelefi'l-Hadis adlı eseri ile metin tenkidinde yeni bir ufuk açmış, Kur'an-1 Kerim'e ya da akla aykırı gibi görünen hadisler arasını bulma ya da yorumlama metodunu iyi kullanmıştır. ${ }^{14}$

\section{B. Mevzû Hadislerin Tenkidinde Metin Bilgi ve Birikimi İle İlgili Ek Kriterler}

Hadis metinlerinin tenkidinde dikkate alınan meşhur temel kriterler yanında birtakım ek kriterler tespit edilmiştir. Hadis münekkitleri, ömür boyu süren ilmî çalışmalar sonunda istikrâ (tümevarım) yoluyla vardıkları bu önemli sonuçları metin tenkidi kriterleri olarak ilim dünyasına takdim etmiş, bu kriterler ilim erbabı arasında "genel kabul" görmüştür. Metin bilgi ve birikimi ile yakından ilgili olarak tespit edebildiğimiz bu önemli ek kriterlerden bazıları şunlardır.

\section{Hadis metninin tamamı veya bir kısmı erken dönem hadis kaynak- larında hiç bulunmazsa, bu durumda, hadisin mevzû/uydurma olduğuna hükmedilir.}

Hz. Peygamber'den nakledilen hadislerin hicri VI. asrın sonlarına kadar tedvin ve tasnif edildiği bilinmektedir. Dolayısıyla erken dönem hadis kaynaklarında bulunmayan bir hadisin sahih hadis olamayacağı belirtilmiştir.

Süyûtî bu konuda, "Ehli nezdinde araştırılan, ama râvilerin gönüllerinde ve kitapların băgrında bulunamayan rivayetler, yalan olduğu kesin olan riva-

13 Polat, Metin Tenkidi, s.306.

14 bkz. İbn Kuteybe, Hadis Müdafaası (Te'vilü muhtelefi'l-Hadis), terc. M.Hayri Kırbaşoğlu, 2.bs., Ankara, Otto Yayınları, 2017. 
yetlerdendir, " demiştir. ${ }^{15}$ Nitekim ezan sonrası okunan duada zaman zaman yapılan "ed-Derecetü'r-Refía" ilâvesi hakkında, İbn Hacer el-Askalânî ve Sehavî (ö. 902/1496): "Bu ilâveyi rivayetlerin hiç birinde görmedim," demiş, ${ }^{16}$ erken dönem kaynaklarında bulunmaması sebebiyle, Ali el-Karî tarafından "mevzu/uydurma" olarak kabul edilmiştir. ${ }^{17}$

\section{Hadis hakkında münekkit bir hadis âliminin "Bilmiyorum" ifadesi ha- disin mevzu/uydurma olduğunu gösterir.}

Bazı hadis imamlarının bazı hadisler hakkında zaman zaman; "Bunu bilmiyorum", Bunun aslina vakıf olamadim," "Bu lafizla bilmiyorum”, "Bu lafizla görmedim”, "Bunu bulamadım”, "Bunu bu şekilde bulamadım”, "Bu konuda hiç bir şey varid olmadl", "Ne bunu tahric eden kimse, ne de isnadı biliniyor" ve benzeri ifadeler kullandığ görülmektedir. ${ }^{18}$

Ömrünü hadis ilmine vermiş, alanında yetkin ve uzman olan bir muhaddisin bilmediği sahih bir hadisin bulunması çok güçtür. Sıradan bir ifade gibi görünen ama aslında muhaddislerin bilgi ve birikiminin ürünü olan bu çeşit ifadeler anlam11 bulunmuş, hadislerin kaynağının sıhhatini tespitte delil olarak kabul edilmiştir.

Meselâ: Buharî'nin üstadı Amr b. Ali el-Fellas'ın (ö.249/864); “Buharî̀nin bilmediği hadis, hadis değildir”, şeklindeki ifadesi, Buharî’nin derinliğinin hocası tarafından takdiridir. ${ }^{19}$

Fahreddin er-Razî (ö.606/1210), Salahaddin el-Alâî (ö.761/1359), İbn Hacer el-Askalânî, Celaleddin es-Süyûtî, İ̉bn Arrak el-Kinânî (ö.963/1556) ve Ali elKarî; hadisler hakkında derin bilgisi olan münekkit bir hadis hafızının, bir hadis hakkında; "Bunu bilmiyorum", demesinin o hadisin Hz. Peygamber'e aidiyetinin reddi konusunda delil olacağını ifade etmişlerdir. Ancak İzzeddin b. Cemâa (ö.767/1366), bu hükmün zann-1 galib ifade edeceğini belirtmiş, Abdülfettah Ebû Gudde ise (ö.1417/1997), bu konuda daha sonraki hadis hafizları tarafindan bir tenkid gelmemiş olması gerektiğini ifade etmiştir. ${ }^{20}$ Ebu Gudde bu listeye Hafız Ziyaeddin Makdisî, İbn Salah, Münzirî, Nevevî, İbn Dakiki'l-Iyd, İbn Teymiyye, Mizzî, Zehebî, Sübkî, Zeylaî, İbn Kesir, İbn Receb, Irakî, Heysemî, İbn

15 Süyûtî, Tedribü'r-râvî, III, 437.

16 Sehavî, el-Makasıdü'l-hasene: s.212; Ali el-Karî, Mirkatü'l-Mefatîh, I, 425.

17 Ali el-Karî, el-Masnû, s.100 hadis no: 132; a.mlf, Uydurma Olduğunda İttifak edilen Hadisler, s.138.

18 Ali el-Karî, el-Masnû, s.25; a.mlf, Uydurma Olduğunda İttifak edilen Hadisler, s.63.

19 Zehebî, Siyeru a'lâmi'n-nübelâ, XII, 420.

20 Süyûtî, Tedribü'r-râvî, III, 440; Ali el-Karî, Masnû, s.25-27. 
Hacer, Sehavî ve Süyûtî gibi son dönem hadis hafızlarının da ilave edilebileceğini söylemiştir. ${ }^{21}$

Dolayısıyla hadis ilminde derinleşmiş âlimlerin bir rivayet hakkında söylediği "bilmiyorum, vâkıf olamadım" sözleri, o rivayetin uydurma olduğunu gösterir. ${ }^{22}$

\section{3. İsnadı problemli bazı hadisler hakkındaki "Mânâsı doğrudur" ifadesi hadisin sahih olduğunu göstermez.}

Hadis diye nakledilen isnadı problemli bazı metinler, "mânası doğru" denilerek kabul edilmiştir. Böyle bir ifadenin kullanılabilmesi, Kur' an ve Sünnet bilgisindeki derinlikle yakından ilgilidir. Ancak hadisin mânâsının doğru olması, hadisin sıhhatini tespit kriteri olarak kabul edilmemiş, o sözün konusunun kültürel değerini ortaya koyan bir kriter olarak kabul edilmiştir.

Sehavî el-Makasıdü'l-Hasene'de hadis diye nakledilen ama hadis olmayan bazı ifadeler için; "mânâsı doğrudur", ifadesini kullanmıştır. ${ }^{23}$ Ancak "Selâmeti isteyen kimse selâmette olur", (من طلب السلامة سلم) "24 hadisi için Sehavî, "mânâs1 sahihtir" derken, Ali el-Karî ise; "hadis değildir", ifadesine yer vermiştir. ${ }^{25}$

Yine İhyâ 'da geçen “Mü'min kindar değildir” (المؤمن ليس بحقود) hadisi için Hafız Zeyneddin el-Irakî: "Onun aslına vâkıf olamadım”, demiş ${ }^{27}$, Ali el-Karî ise, ${ }^{28}$ "mânası doğrudur, bundan murad, kâmil mü'mindir. Nitekim âyette; "Biz onların gönüllerinden kin ve hasedi çıkardık, "29 buyurulmaktadır, demiştir. Aclûnî de (ö. 1162/1749), Keşfu'l-Hafa'da; "Hayır, Allah'ın tercih ettiği şeydedir" (الخيرة فيما اختاره اله) hadisi hakkında "manası doğrudur, fakat bu ifadeyi hadis veya eser olarak bilmiyorum," şeklinde görüş beyan etmiştir." 11

21 Ali el-Karî, Uydurma Olduğunda İttifak edilen Hadisler, s.64, dipnot 73.

22 Aydınlı, Hadis Istılahları Sözlü̈̆̈̈, s. 162.

23 Sehavî, el-Makasıdü'l-hasene, s.95, hadis no: 183; s.231, hadis no: 532; s.208, hadis no: 468; s.418, hadis no: 1145; s.466, hadis no: 1306.

24 Sehavî, el-Makasıdü'l-hasene, s.418 hadis no: 1145; Aclûnî, Keşfü'l-hafâ, II, 342 hadis no: 2536.

25 Ali el-Karî, Masnû, s.189, hadis no: 347.

26 Gazzâlî, İhyâ: I, 46; Sehavî, el-Makasıdü'l-hasene, s.438 hadis no: 1226; Aclûnî, Keş̧ü 'l-hafâ, II, 387 hadis no: 2685.

27 Gazzâlî, a.g.e. I, 46 dipnot.

28 Ali el-Karî, el-Esraru'l-merfûa, s.351, hadis no: 546; Ali el-Karî, Masnû, s.153, hadis no: 263.

29 A'raf, 7/43; Hicr, 15/47.

30 Gazzâlî, Ihyâ: I, 46; Sehavî, el-Makasıdü'l-hasene, s.438 hadis no: 1226; Aclûnî, Keşfü 'l-hafâ, II, 387 hadis no: 2685.

31 Bkz. Aclûnî, Keş̧ü'l-hafâ, I, 478 hadis no:1273. 
Öte yandan Muhyiddin İbn Arabî (ö.638/1240), Mevlâna Celâleddin er-Rûmî (ö.672/1273), İsmail Hakk1 Bursevî (ö.1137/1725) ve Abdülhakim Arvasî (ö.18651943) gibi tasavvuf erbabının bazı çok zayıf ve mevzû hadisler için "mânâsı doğrudur" ifadesini hadisin sihhati konusunda belirleyici bir ifade olarak kullanmaları, hadis âlimleri tarafından tesahül (kolaycılık) olarak adlandırılmış, bu durum hadis imamlarıyla tasavvuf erbabı arasında tartışmalara konu olmuştur. ${ }^{32}$

Meşhur mutasavviflardan Ebu Talib el-Mekkî (ö.386/996), herhangi bir sözün anlam itibariyle doğru olmasını Hz. Peygamber'in o sözü söylemiş olması için yeterli görmektedir. Nitekim bu konuda delil olarak gösterdiği şu rivayet, bunu göstermektedir: "Kim bir hak rivayet etmişse, onu ben söylememiş olsam dahi ben söylemişimdir. Kim de benden bir bâtıl rivayet ederse bilin ki, ben bâtılı asla söylemem. " ${ }^{33}$ Oysa bu rivayet, as1lsız mevzû bir rivayettir. ${ }^{34}$

Bu konudaki ana ilke, hadis hafizı Ebu'l-Haccac el-Mizzî'nin (ö.742/1341) bir soruya verdiği cevap esnasında; "Allah Rasûlü'nün her söylediği hakdır; ama her hak sözü Allah Rasûlü söylemiş değildir", ${ }_{35}$ şeklinde ifade ettiği; manas1 doğru her sözün Hz. Peygamber'e nispet edilemeyeceği ilkesi olmalıdır. Hz. Peygamber'e nispet edilen asılsız ifadelerin sorumluluğunun büyüklüğü, hadis imamlarının bu konudaki aşırı hassasiyetinin haklılığını doğrulamaktadır.

\section{Hadis, sahih hadislere ve mütevâtir sünnete aykırı olamaz.}

Sahih hadislere aykırılık sebebiyle bir hadisin reddedilmesi için sahih hadislerin iyi bilinmesi gerekir. Bu konuda derin sahih hadis bilgisine ihtiyaç vardır. Metin bilgi ve birikimi burada devreye girmekte ve aradaki çelişkiler titizlikle tespit edilmektedir.

Meselâ: (إن اللَّ بستحي أن يُعذّبَ وجهًا مليحًا بالنار) “Allah, güzel yüze Cehennem’de azap etmekten hayâ eder"36 şeklinde hadis diye nakledilen söz; "Allah sizin vücutlarınıza ve yüzlerinize değil, kalplerinize ve amellerinize bakar. ${ }^{{ }^{37}}$ şeklindeki sahih hadise aykırı görülmüştür.

32 Saklan, Hadis Tarihinde Muhaddis Sûfîler, s. 230-240; Yenibaş, "Tasavvuf Hadis İlişkisi Bağlamında Ahmed Ziyaüddin Gümüşhanevî ve Râmûzü'l-Ehâdîs adlı eseri”, EKEV Akademi, sy.59, ss.492.

33 Mekkî, Kûtü'l-kulûb, I, 249; Yenibaş, a.g.m.,EKEV Akademi, sy.59, ss.492.

34 İbn Arrak, Tenzîhü'ş-şerîa, I, 264; Leknevî, Zaferu'l-emanî, thk. Ebu Gudde, s.567 Muhakkık notu

35 Bkz. Süyûtî, Zeylü'l-mevzûat: s.202; Ali el-Karî, Masnû, s.235 dipnot.

36 Halilî, İşad, s.155; Hatib, Tarihu Bağdad, VII, 383; İbnü'l-Cevzî, el-Mevzûatü'l-kübrâ, I, 249; İbn Kayyim, el-Menâru'l-münîf, s.62.

37 Müslim, Sahih, Birr 10 hadis no: 2564; İbn Mâce, Sünen, Zühd, 9 hadis no: 4143; Ahmed b. Hanbel, Müsned, II, 285. 
Hadis âlimlerinin hadis ilimlerindeki kapasitesini takdir edemeyen hadis uydurmacıları, bu konudaki muazzam birikimi fark edememişler, fütursuz davranmaları sebebiyle kolaylıkla deşifre olmuşlardır.

Günümüzde muhataplarının hadis alt yapısının zayıflığını firsat bilen "medyatik hurafeciler" in taze hurafelerle zihinleri bulandırdıkları halde, yavuz hırsız misali, sahih hadisleri iyi bilen ilim erbabını sünnete saygısızlık, bid'atçilik veya zahirîlikle suçlamaları, tekfir, techil ve tefsik etmeleri ilmî hakikatler karşısında bocaladıklarının açık göstergesidir.

\section{Kur'an-ı Kerim'e veya mütevatir sünnete zahiren aykırı gibi görünen hadis, yoruma açık olma durumunda reddedilmez.}

Hadis ilimleri ve hadis metinleriyle rivayet ve dirayetle hemhâl olan ilim erbabı, mücerret muhalefet yerine özde muhalefeti dikkate alacaklar, hükümlerini ona göre vereceklerdir. Mevzû hadisin tespitinde kesin hüküm önemli olup ihtimal ve yorum söz konusu olamaz. Kur'an-1 Kerim'e veya mütevatir sünnete aykırı gibi görünen hadis, yoruma açık ise ya da ana ilkelerle arayı bulma mümkün ise, bu çeşit hadisler bir çırpıda mevzû olarak nitelendirilemez. Nitekim Süyûtî bu konuda: 'Hadisin Kur'an-ı Kerim, mütevatir sünnet veya kesin olan icma'ın delâletine aykırı olması mevzû hadis alâmetlerindendir. Ancak cem yapma (aralarını bulma) imkânı varsa mevzû hadis olarak kabul edilmez." 38 demektedir. Zira Hadis usûlünde özellikle Müşkilü'l-hadis ve Muhtelifü'l-hadis konusunda tercih ve cem' ile ilgili hususlar üzerinde önemle durulmaktadır. Meşhur usûl kaidesine göre; kelâmın i'mali, ihmalinden evlâdır. ${ }^{39}$

İbn Hacer de bu konuda: "Sadece Sünnete muhalif olma kriteri ile hadisin

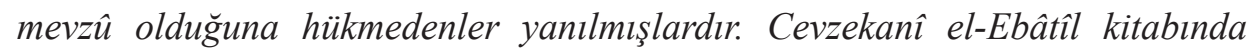
birçok hadis hakkında bu hükmü vermiştir. Oysa bu durum ancak herhangi bir şekilde cem yapılamaması durumunda geçerlidir. Cem yapma (hadislerin arasını bulma) imkânı varsa mevzû hadisten söz edilemez." ${ }^{" 40}$ der.

Yine İbn Hacer, ana ilkelere aykırı gibi görünen ama yoruma açık olan hadisin kolaylıkla reddedilmesinin doğru olmadığına belirterek, çeşitli örneklere yer vermektedir. Nitekim "Ben sizin gibi değilim. Ben yedirilirim, içirilirim", şeklindeki hadis, Hz. Peygamber'in açlıktan karnına taş bağlaması ile ilgili riva-

38 Süyûtî, Tedribü'r-râvî, III, 434.

39 Süyûtî, el-Eşbah, s.128; İbn Nüceym, el-Eşbah, 135, Ali Haydar, Şerhu Mecelleti'l-Ahkâm, s.53, madde 60; Zuhaylî, el-Vecîz, s.259; Ali en-Nedvî, el-Kavaid, s.393; bkz. https://www. alukah.net/sharia/0/90000/

40 İbn Hacer, en-Nüket, II, 846. 
yetlerin bâtıl olduğuna delildir, diyen İbn Hibban'ın (ö.354/965) hatalı olduğunu; Hafız Ziyaeddin el-Makdisî’nin (ö.643/1245) İbn Hibban'a doyurucu ve ikna edici bir şekilde cevap verdiğini kaydetmektedir. ${ }^{41}$

\section{Bir rivayet hakkında; "Hz. Peygamber'in söylemesi imkânsızdır” den- mesi, o rivayetin sahih olmadığına delildir.}

Bir sözün sahibine aidiyetinin reddedilmesi, ancak o söz sahibinin diline, üslûbuna, çağına ve çevresine tam bir vukufla bilinebilir. Sosyal bilimlerde özellikle edebiyatta, şiir tenkidinde uygulanan bu kural, tamamen metin bilgi ve birikimi ile ilgilidir. Sahipsiz şiirlerin sahibinin tespiti, sahibi tartışmalı şiirlerin şairlerinin belirlenmesi için başvurulan bu metot, sübjektif bir metot olmaktan çok; alan uzmanlığı, sürekli araştırma ve derin inceleme gerektirmektedir.

Hz. Peygamber'in bu şekilde bir söz söylemesinin imkânsızlı̆̆ sebebiyle hadis diye nakledilen bazı sözlerin "mevzû" olduğu ifade edilmiştir. Allah Rasûlü’nün nebevî konumu, kullandığı/kullanmadığı kelimeler, çağının ve bölgesinin özellikleri, Arap Dilinin tarih boyu gelişimi dikkate alınarak varılan sonuçlar anlamlı bulunmaktadır.

Nitekim Ebû Hüreyre'nin rivayet ettiği "Salih kölenin iki ecri vardır," hadisi sonunda yer alan; "Nefsimi elinde tutan Allah'a yemin ederim ki, cihad, hac ve anneme iyilik (emri) olmasaydl, köle olarak ölmek isterdim, "42 şeklindeki ifadesi, Allah Rasûlü'ne aidiyet imkânsızlığı sebebiyle merfû olarak kabul edilmemiş, müdrec olarak değerlendirilmiştir.

\section{Mevzû/uydurma hadisler hakkında yapılan genellemeler isabetli olmayabilir.}

"Şu konuda nakledilen hadislerin tamamı mevzudur/uydırmadır", şeklinde yapılan genellemeler, bazen isabetli olduğu halde, bazı konularda isabetli olmamaktadırr. $\mathrm{Bu}$, hadisler hakkında metin bilgi ve birikimi ile ilgili bir konudur. Genelleme yaptığı anda bu konudaki diğer hadisleri hatırlamaması veya kapsam11 araştırma yapmaması sebebiyle yanılan ilim erbabı olmuştur. Firûzâbâdî'nin (ö.817/1415) Sifru's-Saade kitabının hâtime/sonuç bölümündeki genellemeleri, ${ }^{43}$ et-Tenkît ve'l-ifade kitabında tahric eden İbn Himmât ed-Dimaşkî (ö.1175/1761), bu genellemelerin bir kısmının yanlış olduğunu delilleriyle açıklamıştır. ${ }^{44}$

41 İbn Hacer, a.g.e, II, 846.

42 Buhârî, Sahih, Itk 16, hadis no: 2458.

43 Fîrûzâbâdî, Sifru's-saâde, s.273-280.

44 İbn Himmat ed-Dimaşkî, et-Tenkît ve'l-ifade, s.12 vd. 
Metin tenkidi konusunda son derece faydalı bir eser olan el-Menâru'l-münîf adlı eserin müellifi İbnü'l-Kayyim, bazı genellemelerde isabetli görüş ortaya koyamamıştır.

Nitekim, İbnü'l-Kayyim, "Ya Humeyra!.” ifadesi ya da Humeyrâ lafzı geçen her hadis yalandır, uydurmadır," 45 demiş, ancak Mizzî, bu konuda bir hadisi istisna ederek, "Sünen-i Nesaî'de oruç konusunda geçen bir hadis dışında Humeyrâ lafzı geçen her hadis batıldır" ,demiştir. Mizzî'nin talebesi İbn Kesir de (ö.774/1373), Sünen-i Nesaî’ de geçen; “Ya Humeyra!..” diye başlayan ve Mescid-i Nebevî' de kılıç-kalkan oyunu hakkındaki sahih hadisi de bu genellemeden istisna etmiştir. ${ }^{46} \mathrm{Bu}$ arada Abdülfettah Ebu Gudde, bu iki hadisin, elimizdeki matbû Sünen-i Nesâ̂'de bulunmadığını; hadisin büyük bir ihtimalle Nesâ̂'nin Sünen-i Kübrâ'sında geçmiş olabileceğini belirtmektedir. ${ }^{47}$

Hakim'in (ö. 405/1014) Müstedrek'te ${ }^{48}$ Ümmü Seleme validemizden naklettiği, içinde "Ya Humeyra!.." ifadesi geçen üçüncü sahih hadis de genelleme d1şında tutulmalıdır. Bu sebepledir ki, Zürkanî (ö.1122/1710) Ümmü Seleme hadisi hakkında; "İçinde Yâ Humeyrâ ifadesi geçen sahih bir hadistir. Humeyrâ lafzı geçen her hadisin mevzu/uydurma olduğunu iddia eden kimseye bu hadisle cevap verilebilir. "49 demiştir. Zürkanî, bu ifadesiyle büyük bir ihtimalle bu konuda genel hükümler ortaya koyan İbnü'l-Kayyim'i kastetmiş olmalıdır.

\section{Hadis metinlerinin tenkidinde ihtiyatlı ifadeler kullanılmalıdır.}

Hadis metinlerinin tenkidinde tespit edilen kriterlere uygunluk araştırılırken teenni ile hareket etmek, objektif olmak, alanın uzmanlarıla sürekli istişarede bulunmak, derin inceleme ve araştırma yapmak önemlidir.

Hadis üstadı Salahattin Polat hocanın tavsiyesine uyarak; "İçerik tenkidinde hüküm verirken bazı tutku ve saplantılarla hareket etmekten, içinde yaşadığımız şartların bizi etkileyip yönlendirmesinden sakınmamız gerekir. Konjoktürel tenkitlerin, şartların değişmesi ile havada kalacağı unutulmamalıdır." ${ }^{50}$

45 İbnü'l-Kayyim, el-Menaru'l-Münîf: s. 60.

46 Zerkeşî, el-İcabe, s.61-62.

47 İbnü'l-Kayyim, el-Menaru'l-münîf: s. 60, dipnot (2)'nin sonu.

48 Hakim, el-Müstedrek, III, 119.

49 Zürkanî, Şerhu'l-mevâhib, VII, 257.

50 Polat, Metin Tenkidi, s.307. 


\section{Sonuç}

Hadiste Metin Tenkidi, zannedildiği gibi sadece dirayetle ilgili olmayıp aynı zamanda rivayetle ilgili son derece hassas ve titiz çalışma gerektiren önemli bir ilim dalıdır. Metin bilgi ve birikimi, sadece metin ezberlemekle ilgili bir konu olmayıp hadis metinleri hakkında kapsamlı ve karşılaştırmalı bilgi sahip olmayı gerektirmektedir.

İsabetli ve başarılı metin tenkidi, ancak hadis metinleriyle ilgili derin bilgi ve birikim sahibi olmakla mümkündür. Mevzû hadislerin tespit ve tenkidinde bilgi ve birikimi zayıf olanların ya da metinleri değerlendirmede aceleci davrananların isabetli hüküm vermedikleri görülmüştür. Yeterli bilgi ve birikime sahip olmayanların ya da hadis metninin sıhhatini reddederken kolaycılık gösterenlerin kabulde kolaycılık ve gevşeklik gösterenlerle aynı duruma düştügü görülmektedir.

Hadis metinlerinin tenkidinde bilinen temel kriterler yanında istikrâ/tümevarım yoluyla tespit ettiğimiz önemli ek kriterler da bulunmaktadır. Hadisin tamamının veya bir kısmının erken dönem hadis kaynaklarında bulunmaması, hadis hakkında münekkit bir hadis âliminin "Bilmiyorum" ifadesini kullanması, hadisin sahih hadislere ve mütevatir sünnete aykırı olması, ya da zahiren aykırı görünmekle birlikte aynı zamanda yoruma kapalı olması, hadisin Hz. Peygamber tarafından söylenmesinin imkânsız olması hadisin mevzû/uydurma olduğunu gösteren önemli ek kriterler olarak zikredilmektedir. Ancak bir konudaki hadislerin tamamı hakkında hüküm verilirken genelleme yapılmaması, hadis metinlerinin tenkidinde ihtiyatlı ifadeler yerine aceleci ve kolaycı ifadeler kullanılmamas1, ihtiyatl ifadeler kullanılması tavsiye edilmektedir.

Hadis tarihinde metin tenkidi konusunda sürekli gelişim kaydedildiği müşahede edilmektedir. Mevzû hadisler alanında birbirlerini izleyen İbnü'l-Cevzî, Süyûtî ve İbn Arrak el-Kinanî çizgisi gibi, hadis ilimlerinde sonra gelenlerin metin tenkidinde öncekileri tamamlayıcı ve yer yer tashih edici bir çizgi izlemeleri, bu ilim dalının tekâmülünde önemli rol oynamıştır. Disiplinlerarası karşılaştırmalı, titiz ve objektif çalışmalarla metin tenkidinde ilerleme kaydedilmesi mümkündür. 


\section{Kaynakça}

Ahmed B. Hanbel, Kitabü'z-Zühd, Beyrut, Daru'l-Kütübi'l-İlmiyye, 1403/1983.

Ali Haydar, Dürerul-hukkâm şerhu Mecelleti'l-Ahkâm, terc. Fehmî el-Huseynî, 1. bs., Daru'l-Cîl, 1411/1991.

Ali El-Karî, Nûruddin Ebu'l-Hasen Ali b. Sultan Muhammed el-Karî el-Herevî, el-Masnî fì ma'rifeti'l-hadisi 'l-mevzû, thk. Abdülfettah Ebu Gudde, 4. bs., Kahire, 1404/1984.

,el-Esrâru'l-merfûa fi'l-ahbâri'l-mevdûa, thk. Muhammed b. Lutfî es-Sabbağ, el-Mektebü'l-İslâmî, 2. bs., Beyrut, 1406/1986.

, Şerhu şerhi Nuhbeti'l-fiker fi mustalahati ehli'l-eser, thk. Muhammed Nizar Temin ve Heysem Nizar Temim, Beyrut, Daru'l-Erkam, $1415 / 1995$.

, Mirkatü'l-Mefatîh Şerhu Mişkâti'l-Mesâbîh, el-Matbaatü'l-Meymeniyye, Misir, 1309/1891.

, Uydurma Olduğunda İttifak edilen Hadisler, terc. Halil İbrahim Kutlay, 3. bs., İstanbul, İnkılab Yayınları, 2011.

Aydınl, Abdullah, Hadis Istılahları Sözlüğ̈̈, İstanbul, Marmara Üniversitesi İlahiyat Fakültesi Vakfi Yayınları, 2015.

Buhârî, Ebu Abdillah Muhammed b. İsmail el-Buhârî, es-Sahih (bkz. İbn Hacer, Fethu'l-barî).

Fîrûzâbâdî, Mecdüddin Ebu Tahir Muhammed b. Yakub, Min Hedyi'r-Rasûl sallallahu aleyhi vesellem el-müsemmâ Sifrü s-Saâde, Ahmed Abdürrahim es-Said ve Ömer Yusuf Hamza, 1. bs., Misr, Merkezü'l-Kitab li'n-Neşr, 1417/1997.

Gazzâlî, Ebu Hamid Hüccetü'l-İslâm Muhammed b. Muhammed el-Gazzâlî eş-Şafî̂, İhyâu ulûmi'd-din, Mustafa el-Babî el-Halebî, Misır, 1358/1939.

Hakim, Ebû Abdillâh Muhammed b. Abdillâh el-Hâkim en-Nîsâbûrî, el-Müstedrek ale 's-Sahîhayn, Haydarâbad, Dairetü'l-Maarifi'l-İslâmiyye, 1334/1915.

Halilî, Ebû Ya'lâ Halîl b. Abdillâh b. Ahmed el-Halîlî el-Kazvînî, İrşad fî̀ marifeti ulemâi'l-hadis, Riyad, 1409/1989.

Hatib, Ebû Bekr Ahmed b. Alî b. Sâbit el-Bağdâdî, Tarihu Băğdad, Beyrut, Daru'l-Kütübi'l-Ilmiyye, ts.

, el-Kifâye fî ulûmi'r-rivaye, thk. Ahmed Ömer Haşim, 2. bs., Beyrut, Daru'l-Kitabi'l-Arabî, 1406/1986. 
, el-Câmi'li-ahlâkl'r-râvî ve âdâbi's-sâmi', thk. Mahmud et-Tahhân, Riyad, Mektebetü'l-Maarif, 1402/1983.

İbn Arrâk, Ebü'l-Hasen Nûruddîn (Sa'düddîn) Ali b. Muhammed b. Ali elKinânî ed-Dımaşkī, Tenzîhü' 'ş-şerîa ani'l-ahbâri'ş-şenîati'l-mevzûa, thk. Abdülvehhab Abdüllatif, Abdullah Muhammed es-Siddîk, 1. bs. Beyrut, 1969/1399.

İbnü'l-Cevzî, Cemalüddin Ebu'l-Ferec Abdurrahman b. Ali, el-Mevzûâtü'lkübrâ, thk. Abdurrahman Muhammed Osman, 2. bs., Beyrut, Daru'l-Fikr, 1399/1979.

İbn Hacer, Ahmed b. Ali b. Hacer el-Askalânî, Fethu'l-barî bi-şerhi Sahihi'l-Buhârî, thk. Muhammed Fuad Abdulbakî, tsh. Abdulaziz b. Baz, Beyrut, Daru'l-Fikr, ts.

, Nüzhetü'n-nazar fî mustalahati ehli'l-eser, thk. Nûruddin Itr, Matbaatü's-Sabah, 3. bs., Şam, 1421/2000. , en-Nüket alâ Ulûmi 'l-hadis li'bni 's-Salah, Rabi b. Hadî Umeyr el-Medhalî, el-Camiatü'l-İslâmiyye, 1. bs., Medine-i Münevvere, 1404/1984.

İbn Himmat, Şemsüddin Ebu Abdillah Muhammed b. Hasen ed-Dimaşkî, et-Tenkît ve'l-ifade fî tahric ehadîs hatimeti Sifri's-Saâde, thk. Ahmed el-Berze, I.bsk, 1407/1987.

İbn Kayyim, Ebu Abdillah Muhammed b. Ebîbekr ed-Dimaşkî ed-Dimaşkî, İbn Kayyim el-Cevziyye, el-Menâru'l-münîffi's-sahîh ve'd-daîf, thk. Abdülfettah Ebu Gudde, Haleb, Mektebü'l-matbûâti'l-islâmiyye, 1402/1982.

İbn Kesir, Ebü'l-Fidâ' İmâdüddîn İsmâîl b. Şihâbiddîn Ömer b. Kesîr b. Dav' b. Kesîr el-Kaysî el-Kureşî el-Busrâvî ed-Dımaşkī eş-Şâfî̀, İhtisaru'l-hadis (bkz. Şakir, el-Bâisü'l-hasîs).

İbn Kuteybe, Hadis Müdafaası (Te'vilü muhtelefi'l-Hadis), terc. M. Hayri Kırbaşoğlu, 2. bs., Ankara, Otto Yayınları, 2017.

İbn Nüceym, Zeynüddin b. İbrahim el-Misrî, el-Eşbah ve'n-nezâir, Beyrut, Daru'l-Kütübi'l-İlmiyye, 1419/1999.

Leknevî, Ebu'l-Hasenât Abdülhayy b. Muhammed Abdülhalim b. Muhammed el-Leknevî el-Hindî, Zaferu'l-emanî bi-şerhi Muhtasari's-Seyyid'ş-Şerifi'l-Cürcanî fì mustalahu'l-hadis, thk. Abdülfettah Ebu Gudde, nşr. Mektebü'1-Matbûâti'1-İslâmiyye, 3. bs., Beyrut, 1416/1996.

Mekkî, Ebu Talib Muhammed b. Ali b. Atıyye el-Mekkî el-Acemî, Kîtü'l-kulûb, Kahire, 1310/1893. 
Müslim b. Haccac Ebu'l-Huseyn el-Kuşeyrî en-Neysabûrî, es-Sahîh, thk. Muhammed Fuâd Abdülbâkî, İstanbul, Çağrı Yayınları, 1401/1981.

Nedvî, Ali Ahmed, el-Kavâidü'l-fikhiyye mefhûmuha ve neş'etühâ, Daru'l-Kalem, 2015.

Polat, Salahattin, Metin Tenkidi, İstanbul, Marmara Üniversitesi İlahiyat Fakültesi Vakfı (IFAV) Yayınları, 2010.

Saklan, Bilal, Hadis Tarihinde Muhaddis Sûfiler, İstanbul, İnsan Yayınları, 2012.

Sehavî, Şemseddin Muhammed b. Abdirrahman es-Sehavî, Fethu'l-mugîs bi-şerhı Elfiyyeti'l-Hadis li 'l-Irakî, thk. Ali Hüseyin Ali, Daru'l-İmami't-Taberî, $1412 / 1992$.

, el-Makasıdü'l-hasene fì beyan kesir mine'l-ehadisi'l-müştehera ale'l-elsine, talik Abdullah Muhammed es-Siddîk, 1. bs., Beyrut, Daru'l-Kütübi'l-İlmiyye, 1399/1979.

Süyûtî, Celâlüddin Abdurrahman b. Ebîbekr es-Süyûtî, Tedribü'r-ravî fî şerh Takrîbi'n-Nevâvî, thk. Muhammed Avvame, 1. bs., Cidde, Daru'l-Minhâc, $1437 / 2016$. , Zeylü'l-mevzûât, Leknev, el-Matbau'l-Alevî, 1303/1886. ,el-Eşbah ve'n-nezâir, Beyrut, Daru'1-Kütübi'l-İlmiyye, 1411/1990.

Şakir, Ahmed Muhammed, el-Bâisü'l-hasîs şerhu İhtisari Ulûmi'l-Hadis li’l-Hafiz İbn Kesir, Beyrut, Daru'l-Kütübi'l-İlmiyye, 1370/1951.

Yenibaş, "Tasavvuf Hadis İlişkisi Bağlamında Ahmed Ziyaüddin Gümüşhanevî ve Râmûzü'l-Ehâdîs adlı eseri”, EKEV Akademi Dergisi, yıl 18, say1 59, Bahar 2014; http://www.ekevakademi.org/Makaleler/195119086_25\%20 Hasan\%20YENIBAS.pdf (Erişim tarihi: 20.02.2019)

Zehebî, Ahmed b. Osman ez-Zehebî, Siyeru a'lâmi'n-nübelâ, thk. Şuayb el-Arnaût vd., 4. bs., Müessesetü'r-Risale, 1406/1986.

Zerkeşî, Bahadır b. Abdillah el-Misrî el-Minhacî ez-Zerkeşî, el-İcabe li-îradi me 'stedrakethu Âişe ale 's-sahabe', Şam, el-Matbaatü'l-Haşimiyye, 1358/1939.

Zürkanî, Muhammed b. Abdülbakî b. Yusuf ez-Zürkânî el-Mâlikî, Şerhu'lMevahibi'l-ledünniyye, 1. bs., Misır, Bulak, 1278/1861.

Zühaylî, Vehbe, el-Vecîz fì usûli'l-fikh, Katar, Vezaretü'l-Evkaf, 1427/2006. 
